\title{
Psychometric Properties of an Instrument That Measures Adolescent Attitudes Towards Electronic Waste Management ${ }^{1}$
}

\author{
Yois Pascuas-Rengifo ${ }^{2}$, Jesus Alfonso Beltran-Sanchez ${ }^{3}$ and Bernardo Emilio \\ García-Quiroga ${ }^{4}$ \\ Secretaria de Educación Municipal Florencia Caquetá-Colombia², Tecnológico \\ de Monterrey-México ${ }^{3}$, Universidad de la Amazonia-Colombia ${ }^{4}$
}

The use and consumption of mobile devices are increasing thanks to easy access to this type of technology, which inherently increases the generation of electronic waste. The objective of this study is to determine the psychometric properties of an instrument that measures adolescent attitudes towards the management of electronic waste. A validation of content and construct supported by the application of exploratory and confirmatory factorial analysis was performed. The findings show that this scale could be applied in high school student populations and could be input for various works of research.

Keywords: attitude, electronic waste, adolescents, measurement scale, psychometric properties, educational innovation.

Propiedades psicométricas de un instrumento que mide las actitudes de los adolescentes hacia la gestión de residuos electrónicos

El uso y el consumo de dispositivos móviles están aumentando gracias al fácil acceso a este tipo de tecnología, que aumenta de forma inherente la generación de residuos electrónicos. El objetivo de este estudio es determinar las propiedades psicométricas de un instrumento que mide las actitudes de los adolescentes hacia el manejo de los desechos electrónicos. Se realizó una validación de contenido y construcción respaldada por la aplicación de análisis factorial exploratorio y confirmatorio. Los resultados muestran que esta escala podría

1 Research article derived from the doctoral thesis called "Ecoliteracy and gamification: a didactic alternative to the challenge of electronic waste" within the framework of the Doctorate in Environmental Education and Culture at the Universidad de la Amazonia.

$2 \quad \mathrm{Ph} . \mathrm{D}(\mathrm{c})$ in Education and Environmental Culture at the Universidad de la Amazonia. She currently serves as a classroom teacher at a public educational institution. Contact: y.pascuas@udla.edu.co https://orcid.org/0000-0001-6241-3247

3 Master's degree in educational research. Project Coordinator for the Development of the Faculty and Part-Time Professor at the School of Medicine and Health Sciences in Tecnológico de Monterrey, Mexico. Postal address: Av Morones Prieto No. 3000, Colonia Los Doctores CP 64710. Contact: jbeltrans@itesm.mx https://orcid.org/0000-0003-0930-6033

4 Ph.D. in Pedagogical Sciences by the Central Institute of Pedagogical Sciences (ICCP) in Havana, Cuba. Associate researcher and Colciencias evaluator. Research professor at the Universidad de la Amazonia. Contact: bgarciaquiroga@hotmail.com. https://orcid. org/0000-0002-3599-8742 
aplicarse en poblaciones de estudiantes de secundaria y podría ser aportada para diversos trabajos de investigación.

Palabras clave: actitud, desechos electrónicos, adolescentes, escala de medición, propiedades psicométricas, innovación educativa.

Propriedades psicométricas de um instrumento que mede as atitudes dos adolescentes em relação ao gerenciamento eletrônico de resíduos

O uso e consumo de dispositivos móveis estáo aumentando graças ao fácil acesso a esse tipo de tecnologia, o que aumenta inerentemente a geraçáo de lixo eletrônico. O objetivo deste estudo é determinar as propriedades psicométricas de um instrumento que mede as atitudes dos adolescentes em relaçấo ao gerenciamento de resíduos eletrônicos. Foi realizada uma validação do conteúdo e construto apoiado pela aplicação da análise fatorial exploratória e confirmatória. Os resultados mostram que essa escala pode ser aplicada em populaçóes de estudantes do ensino médio e pode contribuir para vários trabalhos de pesquisa.

Palavras-chave: atitude, lixo eletrônico, adolescentes, escala de medição, propriedades psicométricas, inovação educacional.

Propriétés psychométriques d'un instrument qui mesure les attitudes des adolescents envers la gestion électronique des déchets

L'utilisation et la consommation d'appareils mobiles augmentent grâce à un accès facile à ce type de technologie, ce qui augmente intrinsèquement la génération de déchets électroniques. L'objectif de cette étude est de déterminer les propriétés psychométriques d'un instrument qui mesure les attitudes des adolescents envers la gestion des déchets électroniques. Une validation du contenu et de la construction appuyée par l'application d'une analyse factorielle exploratoire et confirmatoire a été effectuée. Les résultats montrent que cette échelle pourrait être appliquée dans les populations d'élèves du secondaire et pourrait être entrée pour divers travaux de recherche.

Mots-clés: attitude, déchets électroniques, les adolescents, échelle de mesure, propriétés psychométriques, innovation pédagogique. 
Electronic waste generation is expected to increase due to the excessive development of Information and Communications Technologies (ICT). This type of waste includes contaminants and harmful elements, including lead, chromium, mercury, cadmium, and arsenic. Some of these metals persist in the environment and result in contamination through bioaccumulation in plants and animals (Jara, 2017; Londoño et al., 2016). Furthermore, the manufacture of electronic devices requires elements that when extracted destroy ecosystems, river basins, and protected areas, in most cases due to the illegal extraction of minerals, especially in the Amazon (Mongabay-Latam, 2018).

Meanwhile, human beings are unaware of the socio-environmental implications of generating this type of unconventional waste (Pascuas, Cruz et al., 2018). As a response, UNESCO (2017) states within its sustainable development goals that action must be taken on behalf of the climate and to protect the use of sustainable terrestrial ecosystems. According to the above, it is preponderant to analyze environmental behaviors and attitudes, given the deterioration that human beings are causing to ecosystems, especially if one takes into account what is causing the production of electronic devices and the generation of electronic waste.

In the attempt to minimize the negative impact on the environment, instruments have been developed and validated to assess environmental attitudes, thus having, for example, an instrument for measuring pro-environmental attitudes in Venezuelan schoolchildren (Campos et al., 2008). Other research includes an environmental attitudes questionnaire (Corraliza \& Berenguer, 1998), attitudes towards electronic waste recycling in Mexico (Arroyo, 2014), environmental attitudes of children in school (Izadpanahi \& Tucker, 2018; Wu, 2012), attitudes of high school students (DeWaters et al., 2013; Zamorano et al., 2012), of young university students (Herrera et al., 2016), measure- 
ments of the environmental literacy of teachers (Aznar et al., 2019; Boubonari et al., 2013; Farida \& Hadiansah, 2019) and the measurement of eco-spirituality (Suganthi, 2019).

The lack of such scales adapted to the characteristics of the Amazon region, its type of population, and the need to collect information about the problem is significant evidence of the absence of instruments that address the issue of electronic waste. Therefore, this research is geared towards determining the psychometric properties of an instrument to measure attitudes that adolescents (high school students) have toward the management of electronic waste from cell phones and tablets.

\section{Attitudes for prioritizing the environment}

Attitudes are part of human life and behavior; they are learned and acquired in the course of social interactions in various spaces. As they are learned, they are likely to be modified. Hence, there is evidence that attitudes formed on the basis of experiences are stronger in behavior; that is why intense attitudes have a more significant impact on behavior and are more resistant to change. Attitudes are seen as one of the key aspects that are addressed in environmental education for the construction of environmental culture. At the same time, environmental education has been defined as an active methodology for changing attitudes and instilling values favoring the environment, especially in young students. What is sought is to achieve a healthier behavior of the human being in his interactions with the environment (Castanedo, 1995).

In turn, Rokeach (1968) considers attitudes as the organization of various beliefs centered on a specific consideration (physical or social, concrete or abstract, for example), which predisposes a person to respond in a certain way through an action. Attitudes are considered to be manifestations and indicators of the conscious experience, the verbal behavior and daily behavior of a subject or group of them about a situation, object or another person, in order to develop an emotion, learn new knowledge and, above all, to take action. This is how attitudes could be modified over time, through persuasive strategies in 
propitious moments (Briñol et al., 2002; Taborda \& Gonçalves, 2020; Pereyra et al., 2019).

In the meantime, attitudes have a structure made up of three components that interact with each other. The first is the cognitive component that is composed of the beliefs, perception, information, and knowledge that one has about an object. The second component is the affective, considered as the feeling that evaluates the level of liking or displeasure with a social object. Finally, the third component is the behavioral, defined as the tendency and willingness to react, in a certain way, to objects. This dimension also covers both the intentions of conduct and the actions (Aigneren, 2008).

Therefore, an environmental attitude is defined as a predisposition towards actions for or against the environment, and for this reason, an attitude attends the learnings or beliefs about the subject and the willingness (favorable or unfavorable) to act in a determined direction. Positive environmental attitudes are the opinions that are held about protecting the environment and conserving resources, and they influence behaviors. Beliefs and attitudes influence values and, in turn, affect the way of life of human beings and their environment (Camacho \& Jaimes, 2016).

In relation to the above, Álvarez \& Vega (2009) define the environmental attitude as "the favorable or unfavorable feelings that are held towards some characteristic of the environment or towards a problem related to it" (p. 247); it is characterized by being a direct determinant of the predisposition towards actions in favor of the environment. The attitudes and the intention to act have a significant influence on behavior when other factors do not prevent it from taking place.

However, it is indicated that there is no correspondence between what humans know and the attitudes with respect to environmentally responsible behavior. There is evidence that interventions to guide environmental education with attitudes do not always give rise to environmentally friendly behaviors, creating an inconsistency between environmental attitudes and behavior. For this reason, lasting changes must be generated in people's behavior; since attitudes are those that 
determine it, they are the elements necessary for changing environmental behavior. It is concluded that behavior is a manifestation of attitude (Páramo, 2017).

In this sense, given the complexity of measuring aspects that could be framed as attitudes, measurement techniques that use scales arise. The scales allow variable attitudinal values to be represented by a score, usually in "questionnaires composed of a set of questions that have a structure of items or propositions used to quantify characteristics or variables of social behavior" (Aigneren, 2008, pp. 1-2).

However, considering that in some cases, people tend to give socially acceptable answers, there may be an incongruity between what a subject expresses that he does and what he actually does, implying that he is better than he is actually, even in anonymity (Castanedo, 1995). Hence, humanity's challenge in the face of the environmental crisis is to have the coexistence of a high degree of concern and the capacity for social change so that there is a powerful effect that results in environmental sustainability (Moreno et al., 2005).

\section{Method}

A quantitative study was conducted with a defined scope and a trans-sectional survey design. This type of research design is commonly used in social or behavioral science research and consists of the application of surveys or instruments for measuring variables of interest, where quantitative or numerical data are collected which will ultimately be analyzed quantitatively (Creswell, 2009; Ornstein, 2013; Ruel et al., 2016).

\section{Sample}

A non-probabilistic sampling was used for convenience, where there was a collaboration of 447 students, of whom 231 (51.7\%) were male and $216(48.3 \%)$ female; they also reported ages of 13.9 years $(S D=1.7)$ and $13.5(S D=1.94)$, respectively. Participants were from 
two public high school in Florence Caquetá, Colombia; 359 (80.3\%) attended the one educational institution, and 88 (19.7\%) were enrolled in other educational institution. There were six different grades represented (See Table 1).

\section{Table 1}

Participation frequency by academic grade.

\begin{tabular}{llll}
\hline Grade & Frequency & Percentage & $\begin{array}{l}\text { Accumulated } \\
\text { Percentage }\end{array}$ \\
\hline 6 & 109 & 24.4 & 24.4 \\
7 & 103 & 23.0 & 47.4 \\
8 & 90 & 20.1 & 67.6 \\
9 & 57 & 12.8 & 80.3 \\
10 & 30 & 6.7 & 87.0 \\
11 & 58 & 13.0 & 100.0 \\
\hline
\end{tabular}

\section{Measures}

The instrument had as a starting point the proposal of Pascuas, Chico et al. (2018) in terms of identifying the incidence of the level of schooling in attitudes and perceptions about managing this type of waste. A survey-type instrument was organized and adapted with 24 items to be measured using a Likert scale ranging from a value equal to 0 (totally disagree) to 4 (totally agree). It should be noted that easy-tounderstand words and sentences were used for the students; attitudes towards the use of electronic waste, specifically, cell phones and tablets, were defined.

In addition to the above, an exercise in the operationalization of the variable was carried out, where was presented the description or theoretical definition of the different measured dimensions, the authors who supported the said construction, and an example of the behavior (item) that is measured (see Table 2). 


\section{Table 2}

Operationalization of the variable attitude

\begin{tabular}{|c|c|c|c|}
\hline Dimension & Description & Authors & Example of item \\
\hline Affective & $\begin{array}{l}\text { Alludes to the } \\
\text { feelings generated } \\
\text { towards pollution } \\
\text { and destruc } 2 \text { tion of } \\
\text { the Amazon due to } \\
\text { the manufacture of } \\
\text { electronic devices } \\
\text { and the subsequent } \\
\text { generation of } \\
\text { electronic waste. }\end{array}$ & $\begin{array}{l}\text { (García et al., } \\
\text { 2011; Muñoz \& } \\
\text { Dorinda, 2008) }\end{array}$ & $\begin{array}{l}\text { I am saddened by the } \\
\text { pollution generated } \\
\text { by the manufacture } \\
\text { of devices and } \\
\text { the generation of } \\
\text { electronic waste. }\end{array}$ \\
\hline Cognitive & $\begin{array}{l}\text { The student's } \\
\text { knowledge about } \\
\text { the management } \\
\text { of electronic waste } \\
\text { from cell phones } \\
\text { and tablets }\end{array}$ & $\begin{array}{l}\text { (Hernández } \\
\text { et al., 2002; de } \\
\text { Castro, 2001; } \\
\text { Moon et al., } \\
\text { 2017) }\end{array}$ & $\begin{array}{l}\text { I consider myself one } \\
\text { more species of the } \\
\text { Amazon ecosystem. }\end{array}$ \\
\hline Behavioral & $\begin{array}{l}\text { The behavioral } \\
\text { tendency toward } \\
\text { the management } \\
\text { of electronic waste } \\
\text { from cell phones } \\
\text { and tablets }\end{array}$ & $\begin{array}{l}\text { (Cabas \& de } \\
\text { Durán, 2010; } \\
\text { Villacieros et al, } \\
\text { 2018) }\end{array}$ & $\begin{array}{l}\text { I am giving another } \\
\text { person, whom I } \\
\text { can help, the parts } \\
\text { or damaged device } \\
\text { when I send my cell } \\
\text { or tablet to be fixed. }\end{array}$ \\
\hline
\end{tabular}

\section{Procedure}

The following steps were carried out for the purpose of this study:

(1) Request authorization from the directors of the educational institutions.

(2) Delivery of the consent form informing the parents about the voluntary participation of students.

(3) Adaptation of the measuring instrument from the Google docs online forms. 
(4) Application of the measuring instrument to the students in the computer room of the respective institutions.

(5) Data capture and analysis, using the Statistics and AMOS statistical packages from the software, Statistical Package for the Social Sciences (SPSS) version 26.

(6) Interpretation and publication of results.

\section{Data analyses}

Was performed the Exploratory Factor Analysis with Principal Components extraction method and Varimax orthogonal rotation, to determinate construct validity; likewise, was used the Blartlett sphericity test and Kaiser-Meyer-Olkin values to evaluate the model fit and the pertinence.

On the other hand, was used Confirmatory Factor Analysis with structural equation modeling and supported by SPSS AMOS version 26. To determinate the suitability of the model, the following index were evaluated:

- Absolute adjustment index:

- Likelihood ratio (X2)

- Discrepancy between variance and covariance matrices (CMIN / df)

- Goodness of fit (GFI)

- $\quad$ Root Mean Square Residual (RMR)

- Incremental adjustment index:

- $\quad$ Normed Fit Index (NFI)

- Incremental Index of Fit (IFI)

- Comparative Fit Index (CFI)

- Parsimony index

- Root mean square of approximation (RMSEA)

Finally, the reliability was evaluated by the internal consistency index obtained using the Cronbach's alpha. 


\section{Results}

\section{Content Validity}

This activity involved eight professors with research experience in the fields of education, environment, and technology; they were representatives of five different recognized universities in Mexico, Brazil, and Colombia. The judges were given a battery of 24 items organized in three dimensions; namely, affective, cognitive, and behavioral.

With respect to the opinion, comments, observations, and suggestions received by the participating experts and in accordance with Escobar and Cuervo (2008), if $80 \%$ of the experts have agreed on the validity of an item, it can be incorporated into the instrument; otherwise, it must be modified, adjusted, or relocated among the three components and/or new items in the instrument must be created. In general, 18 attitudes met this criterion. Table 3 summarizes the decisions of the experts to make changes to the attitudes contained in the instrument; the actions carried out as a result of this revision led to the adjustment of items and the drafting of new attitudes, resulting in an increase in the number of items in the instrument.

\section{Table 3}

Decisions to adjust the instrument based on the judgment of the experts.

\begin{tabular}{llllll}
\hline \multirow{2}{*}{ Dimension } & \multicolumn{5}{c}{ Number of items } \\
\cline { 2 - 6 } & Initial & Relevant & Adjusted & Incorporated & Final \\
\hline Affective & 7 & 3 & 4 & 7 & 14 \\
Behavioral & 9 & 5 & 4 & 1 & 10 \\
Cognitive & 8 & 3 & 5 & 3 & 11 \\
Total & 24 & 11 & 13 & 11 & 35 \\
\hline
\end{tabular}




\section{Construct Validity}

Exploratory factorial analysis

The Exploratory Factor Analysis (EFA) was performed using the method of extraction from a principal components analysis and a Varimax rotation. The results of the Bartlett Sphericity test $\left(\chi^{2}=\right.$ $470.87, p \geq .000, g l=36$ ) and the Kaiser-Meyer-Olkin (KMO) value of .82 serve as evidence to claim that the proposed model has a good fit (Cea, 2002; Martínez et al., 2009).

In addition, two criteria were used for the inclusion of items: (1) factorial load greater than .40 , a criterion suggested for samples of 200 participants (Hair et al., 1999) and (2) communalities greater than .30 and less than .75 (De Vellis, 2009; Field, 2009). Once these criteria were met, a two-factor solution was obtained that explains $55.17 \%$ of the variance with nine items (Merenda, 1997) (Table 4).

\section{Table 4}

Factorial analysis of the two factors and the communalities (Annexed 1)

Items

Factorial Loads

F1 F2

I am interested in knowing how to help keep the Amazonian ecosystem free of electronic waste.

It angers me to hear about episodes of pollution caused by electronic wast e, as well as deforestation, illegal mining, .72 contamination of the river by mercury.

I would like to teach and sensitize my family, neighbors, and friends about electronic waste and the problems $\quad .70$ they generate.

I am saddened by the pollution generated by the manufacture of devices and the generation of electronic .69 waste.

I would be very happy if electronic devices and waste didn't contaminate planet earth. 
Items

Factorial Loads

F1 F2

I would like to participate actively in the recycling processes of electronic waste.

I am giving another use to the electronic parts of cell phones or tablets that no longer work, such as doing crafts and/or science projects.

I take to a specialized collection site the parts or damaged device when I send my cell phone or tablet to be fixed.

I am giving another person, whom I can help, the parts or damaged device when I send my cell or tablet to be fixed.

\section{Confirmatory factor analysis}

According to the results of the EFA, a model to measure "high school students' attitudes toward electronic waste management" is proposed, which is composed of two factors: (1) the behavioral approach and (2) the affective approach (see Figure 1).

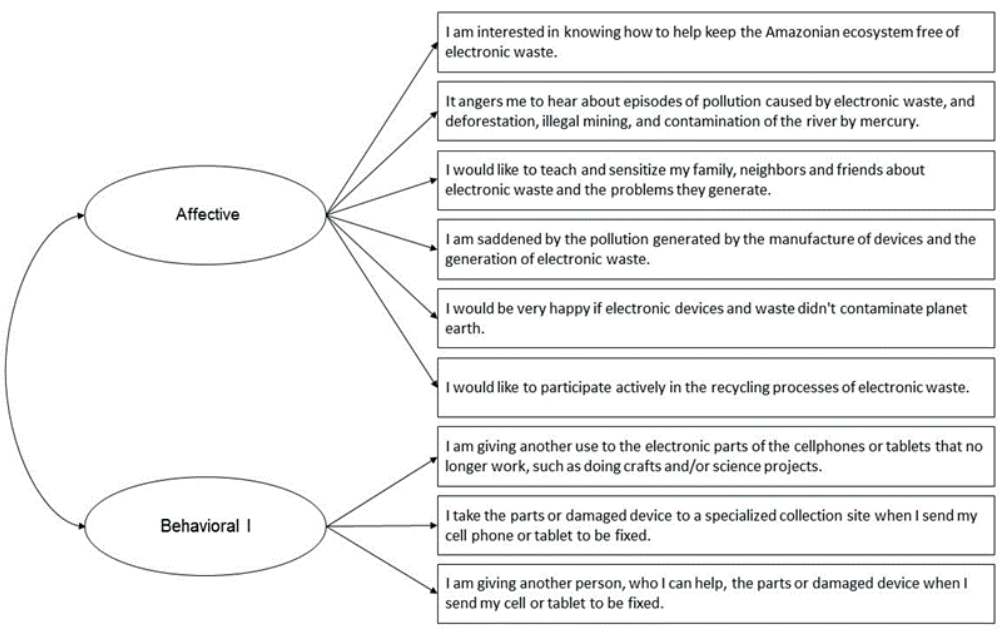

Figure 1. A theoretical model for measuring adolescent attitudes towards electronic waste management. 
Subsequently, for the verification of the model, an exercise of structural equations was performed, where the method of maximum likelihood estimation was used for the determination of the goodness of fit between the theoretical model and the empirical, thus obtaining a satisfactory adjustment, which can be seen in the indices presented in Table 5.

\section{Table 5}

Indices of adjustment of the model to measure attitudes.

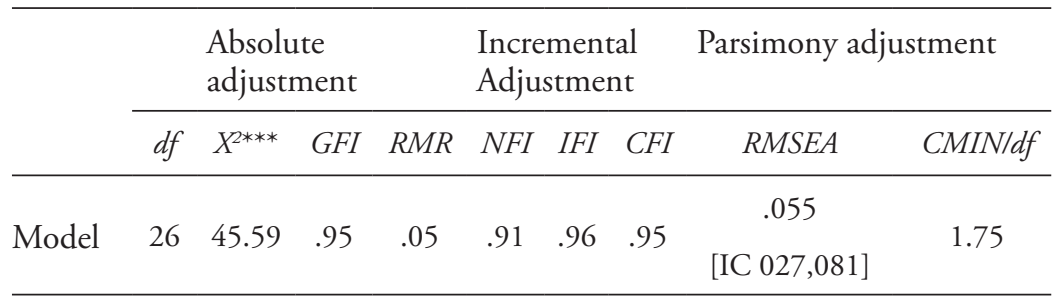

$p=.010$

From the results shown above, it is possible to affirm that there are no significant discrepancies between the variance-covariances matrices observed and those predicted by the model; this assertion is also based on correlations between the factors and significant regression coefficients (see Figure 2). 


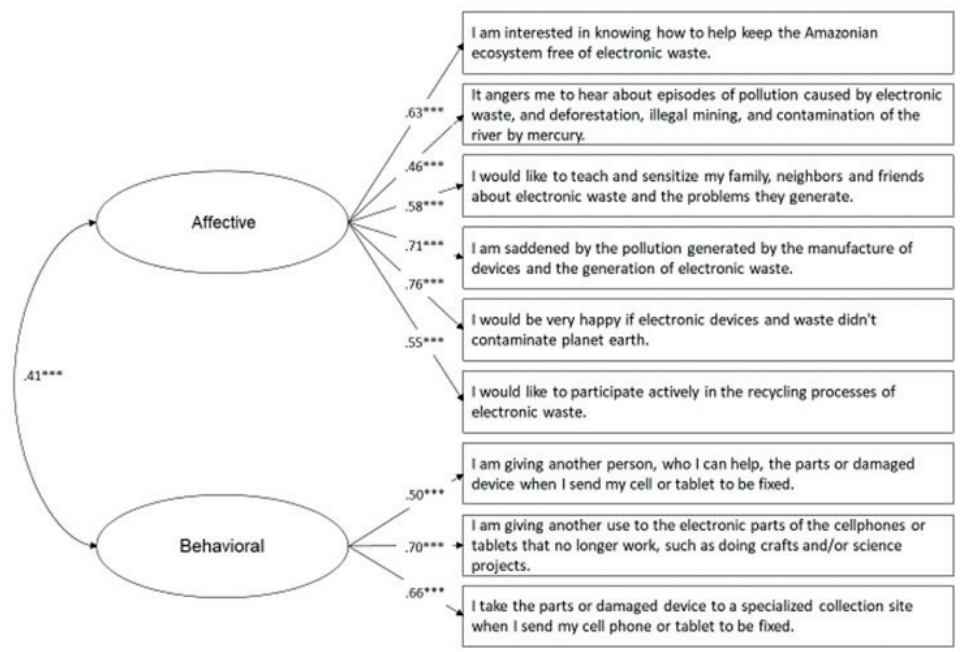

Figure 2. An empirical model of the scale for measuring adolescent attitudes towards electronic waste management.

\section{Reliability}

Reliability was determined through the analysis of internal consistency using Cronbach's alpha. In Table 6, it is possible to observe that the correlations between the elements exceed the minimum value of .30 determined for consideration in the analysis, while the scale shows a reliability of .75 , resulting in an acceptable score according to (De Vellis, 2009).

\section{Table 6}

Consistency Analysis

Items

I am interested in knowing how to help keep the Amazonian ecosystem free of electronic waste.

It angers me to hear about episodes of pollution caused by electronic waste, and deforestation, illegal mining, and contamination of the river by mercury. 
Items

Item Correlation

Scale

I would like to teach and sensitize my family, neighbors, and friends about electronic waste and the problems they generate.

I am saddened by the pollution generated by the manufacture of devices and the generation of electronic .56 waste.

I would be very happy if electronic devices and waste didn't contaminate planet earth.

I would like to participate actively in the recycling processes of electronic waste.

I am giving another use to the electronic parts of cell phones or tablets that no longer work, such as doing crafts and/or science projects.

I take my cell phone or tablet to a specialized collection site when I send the parts or damaged device to be fixed.

I am giving another person, whom I can help, the parts or damaged device when I send my cell or tablet to be fixed.

\section{Conclusions}

Proposing and discussing experiences of attitudes towards the use of mobile devices and things related to electronic waste is an emerging topic little consolidated. Similarly, there are not enough studies analyzing attitudes towards the management of electronic waste from and for the Colombian Amazon region. This is how, in the face of the environmental problems generated by this type of waste, the need and urgency to develop this kind of research for the entire population is evident.

The instruments for determining psychometric properties and the measurement scales are a priority for addressing environmental issues. The contribution of instruments that measure attitudes towards 
environmental conservation is broad and undeniable; however, not all report evidence of the validity and reliability of the data they collect, which leaves in doubt the results that are derived from them. Additionally, there are those that only report reliability (Campos et al., 2008; Corraliza \& Berenguer, 1998; Farida \& Hadiansah, 2019; Herrera et al., 2016; Zamorano et al., 2012), although these have results that may be considered desirable in terms of internal consistency, i.e., scores less than .90. On the other hand, two instruments have been found that, in addition to reliability, add evidence of construct validity, where one reports a scale with 14 items with low reliability and explaining minimal variance through a method of extraction that, in this last item, is flexible (Izadpanahi \& Tucker, 2018). Finally, a survey was analyzed that used Exploratory Factor Analysis, resulting in four subscales with regular KMO scores and some desirable Confirmatory Factorial Analysis indices of adjustment (Aznar et al., 2019).

The analysis of the instrument resulted in an empirically sustainable and parsimonious two-dimensional measurement model, given that it consists of a total of nine items. The adjustment of the instrument to measure attitudes in adolescent students determines that it is sustainable to be used. Despite being a two-dimensional instrument, it would support decision-making in research. It is therefore recommended to continue with this instrument and confirm the presented results of environmental attitudes of adolescent high school students towards electronic waste management. In addition, this would allow teachers and researchers to gather evidence on environmental issues, highlighting that it is likely to be improved with new validation processes.

This analysis helps to explore and identify characteristics of attitudes towards electronic waste among high school students in Florence Caquetá, a population group similar to many others in Colombia and Latin America. This indicates that the construction of a theoretical model that includes the identified factors should be continued. In this way, its usefulness is multiplied, serving both the purposes of research and the construction of environmental culture. Finally, quantitatively 
understanding attitudes could play an important role among the adolescent students; indeed, through the quantification and application, various factors could be identified (personal, school, family, sociodemographic, contextual) to which environmental educational strategies should be targeted and prioritized.

\section{Acknowledgments}

The authors convey their gratitude to the young people, their parents and the schools for their collaboration to make possible this publication; additionally, a special mention to the experts in content for their invaluable comments which undoubtedly made it possible to elevate the quality of the instrument. The authors would like to acknowledge the technical support of Writing Lab, TecLabs, Tecnologico de Monterrey, Mexico, in the production of this work.

\section{References}

Aigneren, M. (2008). Técnicas de medición por medio de escalas. La sociología en sus escenarios, 18. Retrieved from: http:// aprendeenlinea.udea.edu.co/revistas/index.php/ceo/article/ view/6552/6002

Álvarez, P., \& Vega, P. (2009). Actitudes ambientales y conductas sostenibles. Implicaciones para la educación ambiental. Revista de Psicodidáctica, 14, 245-260. Retrieved from: https://www. redalyc.org/pdf/175/17512724006.pdf

Arroyo, P. (2014). Design of e-waste recycling programmes taking participant motivations into account: An exploratory study in the State of Mexico. Psyecology, 3(1), 3-14. https://doi. org/10.1174/217119712799240323

Aznar, I., Hinojo, F., Cáceres, M., Trujillo, J., \& Romero, J. (2019). Environmental Attitudes in Trainee Teachers in Primary 
Education. The Future of Biodiversity Preservation and Environmental Pollution. International Journal of Environmental Research and Public Health, 16(3), 362. https://doi.org/10.3390/ ijerph 16030362

Boubonari, T., Markos, A., \& Kevrekidis, T. (2013). Greek Pre-Service Teachers' Knowledge, Attitudes, and Environmental Behavior Toward Marine Pollution. The Journal of Environmental Education, 44(4), 232-251. https://doi.org/10.1080/00958964 .2013 .785381

Briñol, P., Horcajo, J., Becerra, A., Falces, C., \& Sierra, B. (2002). Cambio de actitudes implícitas. Psicothema, 14(4), 771-775. Retrieved from: http://www.psicothema.com/psicothema. asp?id=797

Cabas, D. M., \& de Durán, J. A. (2010). Actitud investigativa en estudiantes de pregrado: indicadores conductuales, cognitivos y afectivos. Multiciencias, 10, 254-258. Retrieved from: http:// www.redalyc.org/pdf/904/90430360040.pdf.

Hernández, G., González, V., Fernández, L., \& Infante, O. (2002). Actitud ante la muerte en los Médicos de Familia. Revista Cubana de Medicina General Integral, 18(1), 11.

Camacho, D.E., \& Jaimes, N.E. (2016). Relación entre actitudes y comportamientos ambientales en estudiantes de enfermería. Luna Azul, 43, 341-353. https://doi.org/10.17151/luaz.2016.43.15

Campos, M., Pasquali, C., \& Peinado, S. (2008). Evaluación psicométrica de un instrumento de medición de actitudes proambientales en escolares venezolanos. Paradigma, 9(2). Retrieved from: http:/www.scielo.org.ve/scielo.php?pid=\$1011-2251200 8000200008\&script=sci_arttext\&tlng=en

Castanedo, C. (1995). Escala para la evaluación de las actitudes pro-ambientales (EAPA) de alumnos universitarios. Revista Complutense de Educación, 6(2), 26. Retrieved from: https:// dialnet.unirioja.es/servlet/articulo? codigo=150169

Cea, M. (2002). Análisis multivariable: teoría y práctica en la investigación social. España: Síntesis. 
Corraliza, J. A., \& Berenguer, J. (1998). Estructura de las actitudes ambientales: ¿orientación general o especialización actitudinal? Revista de Psicología Social, 13(3), 399-406. https://doi. org/10.1174/021347498760349643

Creswell, J. W. (2009). Mapping the Field of Mixed Methods Research. Journal of Mixed Methods Research, 3(2), 95-108. https://doi. org/10.1177/1558689808330883

de Castro, R. (2001). Naturaleza y funciones de las actitudes ambientales. Estudios de Psicologia, 22(1), 11-22. https://doi. org/10.1174/021093901609569

De Vellis, R. (2009). Scale development. Theory and applications. Thousand Oaks, CA: SAGE.

DeWaters, J., Qaqish, B., Graham, M., \& Powers, S. (2013). Designing an Energy Literacy Questionnaire for Middle and High School Youth. The Journal of Environmental Education, 44(1), 56-78. https://doi.org/10.1080/00958964.2012.682615

Escobar, J., \& Cuervo, Á. (2008). Validez de contenido y juicio de expertos: una aproximación a su utilización. Avances en Medición, 6, 27-36. Retrieved from: http://www.humanas.unal. edu.co/psicometria/files/7113/8574/5708/Articulo3_Juicio_ de_expertos_27-36.pdf

Farida, I., \& Hadiansah. (2019). Development of environmental literacy of student teachers on Green Living theme. Journal of Physics: Conference Series, 1175. https://doi. org/10.1088/1742-6596/1175/1/012177

Field, A. (2009). Discovering Statistics Using IBM SPSS Statistics. USA: SAGE.

García, J., Aguilera, J., \& Castillo, A. (2011). Guía técnica para la construcción de escalas de actitud. Odiseo Revista Electrónica de Pedagogía, 8(16). Retrieved from https:/www.odiseo.com. $\mathrm{mx} / 2011 / 8$-16/garcia-aguilera-castillo-guia-construccionescalas-actitud.html

Hair, J., Anderson, R., Ronald, T., \& Black, W. (1999). Análisis Multivariante. Madrid: Prentice-Hall. 
Herrera, K., Acuña, M., Ramírez, M., \& de la Hoz, M. (2016). Actitud y conducta pro-ecológica de jóvenes universitarios. Opción, 32(13). Retrieved from: http://repositorio.cuc.edu.co/ bitstream/handle/11323/1329/Actitud\%20y\%20conducta $\% 20$ pro-ecol\%C3\%B3gica\%20de.pdf?sequence $=1$

Izadpanahi, P., \& Tucker, R. (2018). NEP (Children@School): An Instrument for Measuring Environmental Attitudes in Middle Childhood. Australian Journal of Environmental Education, 34(1), 61-79. https://doi.org/10.1017/aee.2017.25

Jara, E. (2017). Acumulación de metales pesados en Calamagrostis rigida (Kunth) Trin. ex Steud. (Poaceae) y Myriophyllum quitense Kunth (Haloragaceae) evaluadas en cuatro humedales altoandinos del Perú. Arnaldoa, 24(2), 583-598. https://doi. org/10.22497/arnaldoa.242.24210

Londońo, L. F., Londoño, P. T., \& Muñoz, F. G. (2016). Los riesgos de los metales pesados en la salud humana y animal. Biotecnología en el Sector Agropecuario y Agroindustrial, 14(2), 145. https://doi. org/10.18684/BSAA(14)145-153

Martínez, M., Hernández, M., \& Hernández, V. (2009). Psicometría. Madrid: Alianza editorial.

Merenda, P. F. (1997). A guide to the proper use of factor analysis in the conduct and reporting of research: Pitfalls to avoid. Measurement and Evaluation in Counseling and Development, 30(3), 156-164. https://doi.org/10.1080/07481756.1997.12068936

Mongabay-Latam. (2018). Minería ilegal: estudio revela la peor devastación en la historia de la Amazonía. Semana sostenible. Retrieved from: https://sostenibilidad.semana.com/impacto/articulo/ mineria-ilegal-estudio-revela-la-peor-devastacion-en-la-historiade-la-amazonia/42659

Moon, M. A., Khalid, M. J., Awan, H. M., Attiq, S., Rasool, H., \& Kiran, M. (2017). Consumer's perceptions of website's utilitarian and hedonic attributes and online purchase intentions: A cognitiveaffective attitude approach. Spanish Journal of Marketing - ESIC, 21(2), 73-88. https://doi.org/10.1016/j.sjme.2017.07.001 
Moreno, M., Corraliza, J., \& Ruiz, J. (2005). Escala de actitudes ambientales hacia problemas específicos. Psicothema, 17(3), 502-508. Retrieved from: http://www.redalyc.org/ pdf/727/72717323.pdf

Muñoz, J., \& Dorinda, M. (2008). Vista de Análisis de las actitudes respecto a las matemáticas en alumnos de ESO. Revista de Investigación Educativa, 26(1), 209-226. Retrieved from: https:// revistas.um.es/rie/article/view/94181/90801

Ornstein, M. (2013). A companion to Survey Research. London: SAGE. https://doi.org/10.4135/9781473913943

Páramo, P. (2017). Pro-environmental rules: An alternative for reducing the "say-do" gap in environmental education. Suma Psicológica, 24(1), 42-58. https://doi.org/10.1016/j.sumpsi.2016.11.001

Pascuas, Y., Chico, D., \& Hernández, S. (2018). Residuos de celulares y tabletas: Incidencia del nivel de escolaridad en las actitudes y percepciones frente a su manejo. Revista U.D.C.A Actualidad \& Divulgación Cientifica, 21(1), 243-252. https:// doi.org/10.31910/rudca.v21.n1.2018.683

Pascuas, Y., Cruz, L., \& Betancourt, C. (2018). Residuos electrónicos: Análisis de las implicaciones socioambientales y alternativas frente al metabolismo urbano. Ciencia, Docencia y Tecnología, 29(56), 242-252. https://doi.org/10.33255/2956/307

Pereyra, C., Páez, N., del Valle, C., \& Agustina, D. (2019). Validación de la Escala de Autoeficacia para el Afrontamiento del Estrés en estudiantes universitarios. Revista de Psicología, 37(2), 473-493. https://doi.org/10.18800/psico.201902.005

Rokeach, M. (1968). A Theory of Organization and Change Within Value-Attitude Systems. Journal of Social Issues, 24(1), 13-33. https://doi.org/10.1111/j.1540-4560.1968.tb01466.x

Ruel, E., Wagner, W., \& Gillespie, B. (2016). The Practice of Survey Research: Theory and Applications. USA: SAGE. https://doi. org/10.4135/9781483391700 
Suganthi, L. (2019). Eco spirituality: A Scale to Measure an Individual's Reverential Respect for the Environment. Ecopsychology, 11(2), 110-122. https://doi.org/10.1089/eco.2018.0065

Taborda, P., \& Gonçalves, S. (2020). Evidencias de validez de la Escala de Estrés en Estudiantes para universitarios brasileños. Revista de Psicología, 38(1), 65-86. https://doi.org/10.18800/ psico.202001.003

UNESCO. (2017). Educación para los objetivos de desarrollo sostenible. Retrieved from: https://unesdoc.unesco.org/ark:/48223/ pf0000252423

Villacieros, M., Bermejo, J. C., \& Steegman, L. (2018). Ethical attitudes Scale in residences for the elderly. Development of a tool for social and healthcare professionals. Journal of Healthcare Quality Research, 33(6), 352-359. https://doi.org/10.1016/j. jhqr.2018.09.004

Wu, L. (2012). Exploring the New Ecological Paradigm Scale for Gauging Children's Environmental Attitudes in China. The Journal of Environmental Education, 43(2), 107-120. https://doi.org/10.1080/00958964.2011.616554

Zamorano, B., Peña, F., Parra, V., Vargas, J., \& Castillo, Y. (2012). Conocimiento, percepción y actitud ambiental en estudiantes de secundaria. Didáctica ambiental, 8(11), 28-35. 
Annex 1. Instrumento para medir las actitudes hacia el uso de residuos (versión original)

\section{Ítems}

1. Me interesa conocer cómo ayudar a conservar el ecosistema amazónico, de los residuos electrónicos.

2. Me enoja escuchar sobre episodios de contaminación provocada por los residuos electrónicos, al igual que la deforestación, minería ilegal, contaminación de los ríos por mercurio.

3. Me gustaría enseñar y sensibilizar a mis familiares, vecinos y amigos sobre los residuos electrónicos y las problemáticas que generan.

4. Me provoca tristeza la contaminación generada por la fabricación de dispositivos y la generación de residuos electrónicos.

5. Sería muy feliz si los dispositivos y residuos electrónicos no contaminaran el planeta tierra.

6. Me gustaría participar activamente en procesos de reciclaje de residuos electrónicos.

7. Les doy otro uso a las partes electrónicas de los celulares o tabletas que ya no funcionan, como por ejemplo hacer manualidades $y / o$ proyectos de ciencias.

8. Llevo a un sitio de recolección especializado, las partes o el dispositivo dańado, que resulta cuando mando a arreglar mi celular o tableta.

9. Doy a otra persona, quién pudiera servirle, las partes o el dispositivo dańado, que resulta cuando mando a arreglar mi celular o tableta.

Recibido: 13/12/2019

Revisado: $15 / 06 / 2020$

Aceptado: 06/07/2020 